\title{
Beyond Autonomy in Eighteenth-Century British and German Aesthetics
}

Edited by

Karl Axelsson,

Camilla Flodin, and

Mattias Pirholt

First published 2021

ISBN13: 978-0-367-34796-3

\section{Introduction}

Karl Axelsson, Camilla Flodin, and Mattias Pirholt

(CC BY-NC-ND 4.0)

Södertörns högskola 


\title{
Introduction
}

\author{
Karl Axelsson, Camilla Flodin, \\ and Mattias Pirholt
}

Scholars have traditionally claimed that the eighteenth century marks the establishment of modern aesthetic autonomy. A long-standing teleological narrative holds that such autonomy originated in British aesthetic theory, was subsequently given its seminal shape in Kant's Critique of the Power of Judgment, and came to full realization in the poetological and philosophical program of German Romanticism. Lately, this narrative has been reconsidered by philosophers, art historians, and literary historians. The following volume aims to contribute to this ongoing re-examination by charting the aesthetic heteronomy that distinguished the discourse in Britain and Germany by addressing the intimate and often unexpected connections between aesthetic, moral, and scientific concerns in eighteenth-century thought. While every scientific discipline needs a narrative that enables scholars to recognize its history and distinctive borders, an inherent risk with reading the history of aesthetics teleologically is that historical pluralism and aberrant ideas are sacrificed in order to establish and maintain coherence. A motivating force behind the chapters in this volume is the belief that contemporary aesthetics would benefit from engaging further with eighteenth-century ideas seemingly beyond its current naturalized borders.

\section{The Narrative of Modern Aesthetics}

The last two decades have witnessed a "long overdue re-examination of what really did (or did not) happen in the eighteenth century as to our conceptions of aesthetics and the fine arts." In the middle of this debate-indeed, affecting our understanding of the "grand narrative" itself-is Paul Oskar Kristeller's famous thesis, in which the five arts (painting, sculpture, architecture, music, and poetry), which he claims "underlies all modern aesthetics," are believed to constitute "an area all by themselves." 2 The impact of Kristeller's "brief and quite tentative study" is extraordinary. ${ }^{3}$ As one of his recent opponent states, Kristeller's ideas became "established orthodoxy among historians and philosophers of art and by intellectual and cultural historians, and they are now more or less legion." 


\section{Karl Axelsson et al.}

The ongoing debate on the legacy of Kristeller's thesis can be roughly divided into scholars insisting on a so-called discontinuity model, with the eighteenth century signifying a "Copernican revolution" in the concept of art, and those (especially classicists) favoring a continuity model, arguing for a recognition of a mimeticist tradition that connects idea(l)s from antiquity over a wider time-frame. ${ }^{5}$ The concept of aesthetic autonomy, broadly conceived as the independence of art and aesthetic experience, especially from moral, cognitive, and religious concerns, with repercussions on our conceptions of the role of the artist and the nature of the work, plays a significant role in this protracted debate. Given that, as James I. Porter emphasizes, "Kristeller is conflating 'the modern system of the arts' with claims to aesthetic autonomy," he is also

emphatically partial to aesthetic autonomy in its modern form, inasmuch as it stresses that the progress of the arts involved their steady 'emancipation' from their background contexts, which is to say, their becoming autonomous from religion, morality, and other strictures. ${ }^{6}$

In the wake of Kristeller's affirmative conflations, philosophers pursued a more clear-cut origin of aesthetic theory and autonomy in "that classical century of modern aesthetics."7 Along with Joseph Addison's Spectator essays, entitled the "Pleasures of the Imagination" and published in the summer of 1712, the writings of the third Earl of Shaftesbury were, in this context, granted a more settled status than what they had received in the past. ${ }^{8}$ However, while affirmative conflations of modern aesthetics with art and aesthetic experience as separated from other domains of human life was to remain an important feature of contemporary aesthetics, over the last decades, a more dialectical understanding has gained ground in the meta-aesthetic debate. ${ }^{9}$ Thus, Porter reminds us in an Adornian manner that a "negation of relation to a given sphere (culture, religion, morals) involves a necessary entanglement in what is being refused." ${ }^{10}$ In fact, the potential for a dialectical understanding of the relationship between autonomy and heteronomy, in which, from our contemporary standpoint, non-aesthetic concerns are continuously regarded as informing aesthetic experience, and vice versa, could be discerned in the ambivalence voiced by the architects of the teleological narrative. Any claim about Addison and Shaftesbury providing the foundation of modern aesthetic theory, as well as initiating the conceptualization of the aesthetic experience as autonomous, was destined to be shadowed by a series of reservations confusing or even contradicting such claims. Thus, while Kristeller's conflations identified Shaftesbury as "the founder of modern aesthetics," they also contained the reservation that Shaftesbury's philosophy was shaped by classical Greco-Roman thought and that he therefore "did not make a clear distinction between artistic and moral beauty." 11 
This twofoldness was to remain a common feature in accounts aiming to establish the writings of Shaftesbury (and, to some extent, Addison) as the definite source of modern aesthetic autonomy. ${ }^{12}$ A series of influential articles by Jerome Stolnitz, published between 1961 and 1963, demonstrates in all its plainness the nature of these and future teleological accounts. While Stolnitz's theory of the existence of a specific aesthetic attitude has been a target of much criticism since the 1970s, his attribution of the modern concept of aesthetic disinterestedness (a cornerstone in his theory of aesthetic attitude) to Shaftesbury remained influential for a much longer period. Only more recently has it been systematically scrutinized and questioned. ${ }^{13}$ The argument made by Stolnitz was that the "chief impulse in the modern period [was] to establish the autonomy of the aesthetic and that Shaftesbury [was] one of the prime movers." 14 Here, "the aesthetic" is defined in terms of perception, and disinterestedness constitutes the property of this distinctively modern "mode of perceiving," which Stolnitz situates "in the British, beginning with Lord Shaftesbury," rather than in, say, Alexander Gottlieb Baumgarten, who gave the discipline its name by defining aesthetics as the science of sensible cognition (scientia cognitionis sensitivae). ${ }^{15}$ What "marks off modern from traditional aesthetics" is, to Stolnitz, the simple fact that disinterestedness constituted an aesthetic attitude that was firmly detached from other domains of human life. ${ }^{16}$ Once Shaftesbury had "installed" the concept of disinterestedness "at the centre of aesthetic theory," the abyss separating modern aesthetics from its previous obsolete forms was, according to Stolnitz, destined to grow wider. ${ }^{17}$ Here, the ruling principle of modern aesthetics is that a "work of art must be evaluated in respect of its intrinsic structure." 18 Accordingly, the modern conviction that the work of art is "autonomous" and "defies" any "extra-aesthetic criteria" was conceived as the effect of Shaftesbury's concept of disinterestedness. ${ }^{19}$ After all, it is, according to Stolnitz, only in "relation to disinterested perception that the work is autonomous." 20

Up to this point, the causal power of Shaftesbury's concept of disinterestedness is easy to follow. However, in order to do so, scholars had to accept the paradoxical idea that Shaftesbury "denies that there is anything peculiar to aesthetic phenomena," that he only exercised "moral and cognitive criteria of evaluation," and that he was ultimately not even "aware" of the revolutionary aesthetic ideas that he was believed to elaborate and defend. ${ }^{21}$ Somewhat in line with Samuel H. Monk's dated belief that British "eighteenth-century aesthetic has as its unconscious goal the Critique of Judgment" (in which Kant is believed to "bring order out of [the] chaos" that reigned in the "confused seas of English theories"), ${ }^{22}$ Shaftesbury's moral philosophy turned, in Stolnitz's account, into a rather defiant $\operatorname{cog}$ in the teleological narrative. A prerequisite for scholars seeking to establish Shaftesbury's importance in the "history of modern theory" was to "bring out what is in him." 23 Crudely put, what 
was assumed to be hidden in Shaftesbury was an embryonic version of Kantian disinterested pleasure and a self-evident progression toward modern aesthetic autonomy.

\section{Disinterestedness and Nature}

If Shaftesbury's ethically and theologically imbued conception of beauty is, to some extent, a reluctant candidate as instigator of modern aesthetic autonomy, the same can be and has been said about Kant. Limiting aesthetics to reflection solely on manmade works of art is usually considered a significant step in the development of aesthetic autonomy, ${ }^{24}$ whereas Kant found his chief examples of the experience of the beautiful, as well as that of the sublime, in nature. Thus, his focus on natural beauty, and his tendency to privilege it above artistic beauty, makes him a somewhat imperfect fit for accounts that depict Critique of the Power of Judgment as the high tide of the development of the autonomy of art. Kristeller himself misrepresented the first part of the third Critique by claiming that "[i]n his critique of aesthetic judgment, Kant discusses also the concepts of the sublime and of natural beauty, but his major emphasis is on beauty in the arts." ${ }^{25}$ Neglecting the fact that the main examples of beauty are natural objects (flowers, birds, crustaceans), the Kristellerian narrative culminates with Kant's division of the arts in Section $51 .^{26}$

It was Kant's outspoken aim to mediate between the realm of nature and the realm of freedom via aesthetic judgment. ${ }^{27}$ For him, there is a deep affinity between the morally good and the ability to take a direct interest in beautiful nature, that is to say, a desire to let beautiful nature exist for itself (even if this would not be beneficial for an individual human being). Such a contemplative attitude toward nature, which permits it to exist beyond human intentions and purposes, is, for Kant, an indication of moral refinement in human beings. ${ }^{28}$ Indeed, it is reasonable to argue that this might constitute a persisting link between Shaftesbury and Kant, rather than the former introducing, as M. H. Abrams claims, a perceiver's stance of art as "self-sufficient [and] autonomous," which eventually "developed into the full modern formulation of art-as-such in Immanuel Kant's Critique of Aesthetic Judgment [i.e. the first part of the third Critique]." 29

Adherence to the teleological narrative affects the interpretation of both Kant's immediate predecessors, in particular Karl Philipp Moritz, and his successors, the post-Kantian idealists and romantics of the late eighteenth and early nineteenth centuries. While frequently overlooked in British and American accounts, ${ }^{30}$ Moritz, whose most important works on aesthetics were published in the 1780s, is, in a German context, often considered a forerunner or even the instigator of aesthetic autonomy. His definition of the work of art as "complete in itself" and as determined by "inner purposiveness" 31 has prompted scholars to claim that he was 
"the first aesthetician ever, who-two years prior to the publication of Critique of the Power of Judgment-articulated, with total theoretical clarity, the notion of autonomy of art and separated rigorously beauty from the useful." 32 Thus, scholars often emphasize Moritz's claim that beauty in the work of art lacks utility value and that the beautiful work, as an imitation of nature's perfection, constitutes an organic totality. ${ }^{33}$ Nevertheless, for Moritz, the work of art serves external purposes as it, by means of disinterested (that is, unselfish) love, facilitates man's moral elevation toward perfection. ${ }^{34}$

From a teleological standpoint, Moritz supposedly paved the way, not only for Kant ${ }^{35}$ but also for the German classicists of the 1790s, in particular Goethe and Schiller, who knew Moritz personally and admired his work. Thus, aesthetic autonomy is seen as the core of German classicist aesthetics. "[N]o other concept" is, as Wilhelm Voßkamp stresses, "perceived as more characteristic for the epoch of Weimar classicism than aesthetic autonomy." ${ }^{36}$ The German classicists of the late eighteenth century are still assumed to have regarded "self-sufficiency and closure" as key features of the work of art. ${ }^{37}$ From such a point of view, Weimar classicism, with its notion of the autonomous "public sphere of beauty" (schöne Öffentlichkeit), is regarded as essentially an elite culture that dissociated itself from contemporary popular culture, turning "its back to the public" as well as on the contemporary political situation, first and foremost the French Revolution and the War of the First Coalition. ${ }^{38}$ However, the political aspects of this turn toward the aesthetic are difficult to overlook. Even Schiller's writings on aesthetics, which at first glance may appear to be the least ambiguous attempt to promote something like aesthetic autonomy, tried to reconcile, as Frederick Beiser notes, "aesthetic autonomy with moral significance," a "somewhat ironic, indeed paradoxical" endeavor since art was supposed to have "its moral force by virtue of its independence from moral ends." ${ }^{39}$ Still, the ultimate success of this effort has been contested. ${ }^{40}$

If Moritz and Kant are regarded as having separated the disinterested pleasure of aesthetic judgments from moral and cognitive concerns, assertions of the interdependence of these realms by succeeding thinkersJohann Gottfried Herder, for instance ${ }^{41}$ —will regrettably seem antiquated. ${ }^{42}$ Post-Kantians like Hölderlin and Schelling also insisted on the interdependence of aesthetics, morality, and cognition. Though they did not regard Kant as successful in his attempt to reconcile the spheres of human freedom and non-human nature, they argued-even as their emphasis shifted from natural beauty to the beauty of art-that aesthetics remains crucial for the possibility of such a reconciliation. In the System of Transcendental Idealism, Schelling claims that art discloses the common origin of mind and nature. Reminiscent of Kant's description of artistic genius as a gift of nature, enabling the creation of works of art characterized by a similar purposiveness to that of products of nature, ${ }^{43}$ Schelling argues that works of art reconcile the unconscious 


\section{Karl Axelsson et al.}

productivity of non-human nature and the conscious productivity of human mind, thus reflecting the union of the productivities in a sensuous, objective form. ${ }^{44}$ In his "Ueber das Verhältnis der bildenden Künste zu der Natur," he reinterprets one of the oldest conceptions of art in Western aesthetics-art as the mimesis of nature-in accordance with the idea of productive nature: art is mimesis of nature, not as the copy of something "given" (this is a reductive view of nature as a mere object and resource to be exploited by human beings) but as a mimesis of nature's creative power. ${ }^{45}$ Similarly, Hölderlin's own poetry and his theoretical writings emphasize poetry's ability to remember and express human beings' dependence on nature and its primary productivity.

Accordingly, the privileging of aesthetic experience during the long eighteenth century can be read in a different light, disclosing an alternative connection between the British and the German tradition, and revealing the ethics of disinterestedness. Disinterestedness can indeed be regarded as a critical response to the increasing exploitation and mastery of nature which the scientific revolution in the seventeenth century had made possible. ${ }^{46}$ This is one of the ways in which both Shaftesbury and Kant can be said to connect disinterestedness to a higher (non-selfish) interest: namely, the moral interest in a reconciliation with nature. How fundamental this idea is for developing an ideal society is of course much more pronounced in Shaftesbury and the post-Kantian romantics than it is in Kant's critical philosophy.

Thinkers belonging to the romantic generation also work to overcome the Kantian division between the artistic genius and the scientist, as shown in the examples of Johann Wolfgang Goethe and the German physicist Johann Wilhelm Ritter. Here, they can perhaps be said to take their lead from Kant's revealing reflection in Critique of Practical Reason, in which he admits that "an observer of nature" begins to like natural objects that once "offended his senses" when he discovers "the great purposiveness of their organization":

his reason delights in contemplating them, and Leibniz spared an insect that he had carefully examined with a microscope and replaced it on its leaf because he had found himself instructed by his view of it, and had as it were, received a benefit from it. ${ }^{47}$

Thus, the reflective and open approach toward the natural world is relevant in scientific examination and knowledge production. ${ }^{48}$

\section{The Structure of the Book}

This volume is divided into three intersecting parts, the first of which addresses the relationship between aesthetic concepts, morality, and society in the British tradition. Outlining the heteronomy of the discourse 
by exploring the relatedness between aesthetic concepts and ethics, Peter de Bolla's chapter, "The Evolution of Aesthetic Concepts 1700-1800," uses a novel computational method to track the evolution of aesthetic concepts across the anglophone eighteenth century. This method was developed by the Cambridge Concept Lab, and it allows scholars to inspect the alterations in conceptual structures over time from the dataset of Eighteenth Century Collections Online (ECCO). The chapter demonstrates that the supposed distinctions between aesthetic and moral concepts in the period have often been misunderstood, and it recovers the precise lexical environments in which both moral and aesthetic concepts circulated and attained coherence.

The following two chapters by Karl Axelsson and Neil Saccamano, respectively, focus on the assumed origins of aesthetic autonomy by exploring the foundational role attributed to Shaftesbury. Axelsson's chapter, "Beauty, Nature, and Society in Shaftesbury's The Moralists," contributes to the ongoing re-evaluation of Shaftesbury's legacy in aesthetics by addressing two primary matters. First, it zooms in on how the Hobbesian view of nature and society impedes, from Shaftesbury's antivoluntaristic standpoint, a recognition of the intrinsic relatedness that distinguishes man's productive harmony with inner human nature as well as the physical beauty of external nature. Second, in a close reading of the dialogue The Moralists, A Philosophical Rhapsody, this chapter focuses on how Shaftesbury explores this productive relatedness by developing an organic notion of nature and society. For Shaftesbury, society is integrated in the beauty of nature, and vice versa. This integration should grant the concept of society a noteworthy role in aesthetics, and if we wish to be faithful to the temporality of Shaftesbury's philosophy, we must, as this chapter demonstrates, accept that his concept of society is integral to the aesthetic claims he makes about the beauty of nature.

Saccamano's chapter, "Force Makes Right; or, Shaftesbury's MoralAesthetic Dynamics," examines what Ernst Cassirer called Shaftesbury's "purely dynamic standpoint" in order to make visible the irreducible difference of forces in the Earl's writing rather than singling out autotelic, autonomous force. Force functions across various registers in Shaftesbury: aesthetically (the force of the beautiful form), ethically (the force of natural affections), politically and religiously (the force of coercion), socially (the force of affective communication), and philosophically (the force of reason). The chapter shows that affective force must be immediate and involuntary to counter an equally involuntary coercive political force: for both Hobbes and Shaftesbury, force makes right. On the other hand, Shaftesbury also admits that immediate natural affection is not always normatively right from the start, and a just self-formation requires philosophical reflection. Since critical reason must also function as a mediating force, Shaftesbury's writing employs different ways of negotiating the admittedly heteronomous intervention of philosophy, 


\section{Karl Axelsson et al.}

its inquisitorial force, in the supposedly autonomous formation of a self with a just moral-aesthetic taste-the therapeutic labor of aiding selfrecollection or anamnesis, the enchantments of poetry and rhetoric, and the possibility of self-persuasion.

The final two chapters, by Maria Semi and by Emily Brady and Nicole Hall, focus on the middle and late part of the century, re-reading the roles of David Hume and Adam Smith, respectively. While the penultimate chapter by Semi unearths the moral significance of aesthetic experience for Hume, one of the major philosophers of British aesthetics, Brady and Hall make the opposite move: directing attention to a figure more known for his moral philosophy, they reveal an underlying aesthetic psychology in Smith's ethics.

Reading Hume's mid-eighteenth-century work Essays Moral, Political, Literary, Semi argues in her chapter "Civilization in Eighteenth-Century Britain: A Subject for Taste" that the concept of taste-one of the core aesthetic categories of the age-was inextricably connected with ideas about human difference and civilization, and therefore with the domains of morals, history, and politics. To consider taste merely as a capacity for disinterested contemplative pleasure risks reducing the complexity of the eighteenth-century discourse on taste.

Emily Brady and Nicole Hall's chapter, "Adam Smith's Aesthetic Psychology," explores Smith's The Theory of Moral Sentiments as well as his essay on "The History of Astronomy" in order to draw out four themes which suggest an "aesthetic psychology" in his work: (1) the place of aesthetic concepts in The Theory of Moral Sentiments, (2) moral and aesthetic perception, (3) sympathetic attention and imagination, and (4) aesthetic communication. Although Smith did not write extensively on the key aesthetic questions of the time, this chapter demonstrates that, when focusing on his writings on morals and science, aesthetic themes emerge which can extend our understanding of his views on the important aesthetic ideas of his day.

The second part of the volume focuses on the liaisons between British and German discourses. It opens with Paul Guyer's chapter, "Aesthetic Autonomy Is Not the Autonomy of Art," which demonstrates that the autonomy of art is a nineteenth-century idea, not an eighteenth-century one. The eighteenth-century conception of art can thus be called heteronomous, though that is anachronistic. Kant first used the term autonomy in an aesthetic context to characterize aesthetic judgment, not the status of art: for him, aesthetic autonomy means, as Guyer argues, that individual subjects must make their judgments of taste on the basis of their own experiences; it does not imply that the creation or experience of art is exempt from moral constraints. For Kant, nothing in human life is so exempt. Guyer's chapter also addresses other contemporaries of Kant, including Moses Mendelssohn and James Beattie. 
Alexander Gottlieb Baumgarten has long featured in the historiography of aesthetics as a progenitor of concepts, such as aesthetic autonomy, and is familiar to practitioners of the modern discipline. More recently, as this historiography has faced pressure from scholars trying to understand the British and German eighteenth-century emergence of aesthetic theory in relation to moral, political, theological, and other discourses external to the modern discipline, the ostensibly theological roots of Baumgarten's aesthetic theory have come under intense scrutiny. Simon Grote's chapter, "From Spiritual Taste to Good Taste? Reflections on the Search for Aesthetic Theory's Pietist Roots," critically examines the ongoing search for these theological roots in German Pietism. By exposing the complexity and ambiguity of the connection between Baumgarten's concept of good taste and the Pietist concept of spiritual taste, as articulated in the early 1700 s by the teachers from whom Baumgarten received his theological training, the chapter reveals difficulties inherent in the search for intellectual roots per se.

The challenges of pursuing the development of aesthetics as a discipline from the point of view of aesthetic autonomy are further assessed in Anne Pollok's chapter, "Is there a Middle Way? Mendelssohn on the Faculty of Approbation." Pollok argues that Moses Mendelssohn's philosophy, as one influential take on aesthetics in the second half of the eighteenth century, cannot be captured adequately if understood as a mere forerunner to Kant, even though some of his thoughts invite such an interpretation. According to Pollok, this counts in particular for Mendelssohn's Shaftesburian conception of the faculty of approval (Billigungsvermögen), which he develops in the Morning Hours. Read instead in the more appropriate context of Mendelssohn's theory of aesthetic perfection, this mysterious faculty is by no means a sibling of Kant's concept of judgment, nor does it invite the same kind of disinterested pleasure. Rather, Mendelssohn's aesthetics appear as a sophisticated form of aesthetic perfectionism that strives to offer a theory of the interplay of all human faculties. This interplay presupposes a certain freedom within aesthetic appreciation, but, as Pollok argues, it does not neglect the ultimate connection of beauty to perfection or our human interest in it.

Germaine de Staël's On Germany introduced German philosophy not only to French but also to English audiences in the first decades of the nineteenth century and hailed Kant's philosophy as offering a new synthesis of nature and spirit, feeling and reason. Karen Green explores, in her chapter, "Germaine de Staël and the Politics of Taste," the apparent conflict between Staël's aesthetic attitudes, as developed in On Literature-which treats taste as an expression of a historical, national, and cultural moment-and the account of aesthetic autonomy developed in Kant's Critique of the Power of Judgment. The chapter examines how Staël was led to endorse views which apparently conflicted markedly 
with her own and argues that she understood Kant to be offering a philosophical resolution to issues which had been troubling her in works she wrote after the failure of the French Revolution, in which she expressed her belief in cultural progress, despite their putative commitment to cultural relativity. Green concludes with the observation that in spite of Staël's explicit endorsement of Kant's views in On Germany, the outlook of On Literature implicitly undoes the imagined aesthetic autonomy of the Critique of the Power of Judgment.

The third part of the volume addresses science and a new model of society around 1800 . The life-changing experiences that Goethe made during his journey to Italy (1786-1788) had repercussions not only on his aesthetic convictions but also on his scientific conception of nature. In the 1790s, after his return to Weimar, Goethe sought to reform, by means of critical journals, art exhibitions, prize competitions, and new theatrical practices, the art and literature of his age in a neoclassical direction. At the same time, he developed new scientific theories: most notably, his morphology, a pre-Darwinist theory of the evolution of nature. As Mattias Pirholt argues in his chapter, "Goethe's Exploratory Idealism," both Goethe's aesthetic thinking and his scientific research rely on a particular form of experimentalism. The idea-be it that of a natural phenomenon or that of a work of art-is only obtainable by means of exploratory experiments. Rather than being the origin of things, the idea constitutes, as Pirholt demonstrates, the goal of the scientist's or the artist's teleological experimental process.

Jocelyn Holland's chapter, "Physics as Art: Johann Wilhelm Ritter's Construction Projects," approaches aesthetic autonomy and heteronomy through the work of physicist Johann Wilhelm Ritter, someone well versed in the empirical sciences, the speculative physics of Schelling, and eighteenth-century literature. Ritter embraced the work of diverse writers, including Herder, Winckelmann, and Novalis, as is reflected in the concept of art articulated in his fragments, their semi-fictional preface, and the essay "Physics as Art." He also adapted the concept of art to join numerous discourses: theories of chemistry, magnetism, medicine, and optics. Holland's chapter focuses on Ritter's techniques of construction, particularly how he orders bodies and constructs new ones, drawing from both scientific and aesthetic practices. It also shows how, through the formation of new characters and symbols, readers witness the emergence of monuments. The techniques of ordering and construction in Ritter's thinking - from the creation of temporal and conceptual sequences to the emergence of form from the printed page-illustrate an innovative and idiosyncratic model for aesthetic practice.

In the following chapter, "Hölderlin's Higher Enlightenment," Camilla Flodin addresses the importance of self-reflective heteronomy for both art and society. Flodin analyzes Hölderlin's emphasis on the importance of aesthetic comportment for reconceiving the relationship 
between human beings and their surroundings, and for enabling what he calls a "higher enlightenment." He shares the romantic critique of the mechanistic conception of nature and life, and argues that we have to achieve a higher connection than the mechanical one between ourselves and our surroundings. In order to establish this, the bond between human beings and their environment needs, as Flodin stresses, aesthetic representation. Poetry is able to particularize and concretize that which in discursive knowledge remains abstract and removed from life. A necessary feature of a higher enlightenment is, according to Hölderlin, the salutary remembrance that human creations, such as art and society, are not completely autonomous but, in a Shaftesburian fashion, ultimately dependent on nature. As Flodin shows, an authentic poem is not a closed autonomous work of art for Hölderlin but, rather, an open unity which remembers its dependence on nature and thus can be said to reflect on its own aesthetic heteronomy.

In the final chapter of the volume, "Rethinking Disinterestedness Through the Rise of Political Economy," Natalie Roxburgh decouples the understanding of disinterestedness from the reception of the Kantian concept by focusing on British political economic and utilitarian discourses that addresses the transformation of interests into economic interests. Roxburgh reads Adam Smith, William Hazlitt, John Stuart Mill, and Oscar Wilde in order to demonstrate how individuals are conceived as having economic interests managed by a fundamentally disinterested State, something that radically transforms value at a collective level. Aesthetic value, read through this context, is, as Roxburgh shows, heteronomous rather than autonomous. Attitudes toward disinterestedness-and disinterested representation-differ, and they differ in accordance with views on the efficacy and promises of emergent liberal democracy.

\section{Notes}

1 Peter Kivy, "What Really Happened in the Eighteenth Century: The 'Modern System' Re-examined (Again)," British Journal of Aesthetics 52, no. 1 (2012): 61.

2 Regarding the grand narrative, see Nicholas Wolterstorff, Art Rethought: The Social Practices of Art (Oxford: Oxford University Press, 2015), esp. 5-54. For quotation from Kristeller, see Paul Oskar Kristeller, "The Modern System of the Arts: A Study in the History of Aesthetics (I)," Journal of the History of Ideas 12, no. 4 (1951): 497 and 498.

3 Kristeller, "The Modern System of the Arts: A Study in the History of Aesthetics (I)," 498.

4 James I. Porter, "Is Art Modern? Kristeller's 'Modern System of the Arts' Reconsidered," British Journal of Aesthetics 49, no. 1 (2009): 1.

5 On continuity and discontinuity, see Larry Shiner, "Continuity and Discontinuity in the Concept of Art," British Journal of Aesthetics 49, no. 2 (2009): esp. 166-169. For an outline of the discontinuity model and the continuity model, see Karl Axelsson, Political Aesthetics: Addison and Shaftesbury on 


\section{Karl Axelsson et al.}

Taste, Morals and Society (London: Bloomsbury, 2019), esp. 10-18. On the "Copernican revolution" in art, see M. H. Abrams, "Art-as-Such: The Sociology of Modern Aesthetics," in Doing Things with Texts: Essays in Criticism and Critical Theory (New York: W. W. Norton, 1989), 140.

6 Porter, "Is Art Modern? Kristeller's 'Modern System of the Arts' Reconsidered," 18 and 19.

7 Kristeller, "The Modern System of the Arts: A Study in the History of Aesthetics (I)," 496.

8 For Addison's papers on "The Pleasures of the Imagination," published between June 21 and July 3, 1712, see The Spectator, Vol. 3 [no. 411-421], ed. Donald F. Bond (Oxford: Oxford University Press, 1965), 535-582. Peter Kivy encapsulates the general view about Addison's papers in current aesthetics: "Most philosophers who worry about such things [i.e. why begin with Addison] seem to agree that the discipline of aesthetics, as practiced by professional philosophers today, came into being in Britain early in the eighteenth century and that Addison's Spectator papers On the Pleasures of the Imagination is the inaugural work, if any single work is." See Peter Kivy, "Recent Scholarship and the British Tradition: A Logic of Taste-The First Fifty Years," in Aesthetics: A Critical Anthology, 2nd ed., ed. George Dickie, Richard Sclafani, and Ronald Roblin (New York: St Martin's Press, 1989), 255.

9 For an informative account of the recent meta-aesthetic debate over the alleged autonomy or heteronomy of aesthetics, see Casey Haskins, "The Myth of the Autonomy Fault Line in Aesthetics," in Aesthetic and Artistic Autonomy, ed. Owen Hulatt (London: Bloomsbury, 2013), 113-145.

10 Porter, "Is Art Modern? Kristeller's 'Modern System of the Arts' Reconsidered," 17.

11 Paul Oskar Kristeller, "The Modern System of the Arts: A Study in the History of Aesthetics (II)," Journal of the History of Ideas 13, no. 1 (1952): 27.

12 About this twofoldness in regard to Addison's periodical essays, see e.g. Karl Axelsson, "Joseph Addison and General Education: Moral Didactics in Early Eighteenth-Century Britain," Estetika: The Central European Journal of Aesthetics 46, no. 2 (2009): 144-166.

13 For an early critique of Stolnitz's account, see Jorge V. Arregui and Pablo Arnau, "Shaftesbury: Father or Critic of Modern Aesthetics?" British Journal of Aesthetics 34, no. 4 (1994): 350-362. For more recent criticism, see Miles Rind, "The Concept of Disinterestedness in Eighteenth-Century British Aesthetics," Journal of the History of Philosophy 40, no. 1 (2002): 67-87; and Axelsson, Political Aesthetics, esp. 177-199.

14 Jerome Stolnitz, "On the Significance of Lord Shaftesbury in Modern Aesthetic Theory," Philosophical Quarterly 11, no. 43 (1961): 100.

15 Stolnitz, "On the Significance of Lord Shaftesbury in Modern Aesthetic Theory," 98; Stolnitz, "A Third Note on Eighteenth-Century 'Disinterestedness," Journal of Aesthetics and Art Criticism 22, no. 1 (1963): 69; Alexander Gottlieb Baumgarten, Ästhetik, Vol. 1, ed. and trans. Dagmar Mirbach (Hamburg: Meiner, 2007), 10/11 (§1).

16 Stolnitz, "On the Significance of Lord Shaftesbury in Modern Aesthetic Theory," 98.

17 Stolnitz, "On the Significance of Lord Shaftesbury in Modern Aesthetic Theory," 99.

18 Stolnitz, "On the Significance of Lord Shaftesbury in Modern Aesthetic Theory," 99.

19 Stolnitz, "On the Significance of Lord Shaftesbury in Modern Aesthetic Theory," 99. 
20 Stolnitz, "On the Significance of Lord Shaftesbury in Modern Aesthetic Theory," 99.

21 Stolnitz, "On the Significance of Lord Shaftesbury in Modern Aesthetic Theory," 100.

22 Samuel H. Monk, The Sublime: A Study of Critical Theories in EighteenthCentury England (New York: Modern Language Association of America, 1935), 5-6.

23 Stolnitz, "On the Significance of Lord Shaftesbury in Modern Aesthetic Theory," 100. Emphasis added.

24 See e.g. Casey Haskins, "Autonomy: Overview," in The Encyclopedia of Aesthetics, 2nd ed., Vol. 1, ed. Michael Kelly (New York: Oxford University Press, 2014), 247-252.

25 Kristeller, "The Modern System of the Arts: A Study in the History of Aesthetics (II)," 43.

26 See also Porter, “Is Art Modern? Kristeller's 'Modern System of the Arts' Reconsidered," 17-18.

27 Immanuel Kant, Critique of the Power of Judgment, trans. Paul Guyer and Eric Matthews (Cambridge: Cambridge University Press, 2000), 63 [AA $5: 175]$. The purposefulness of nature-in other words, the human ability (through reflective judgment) to regard nature as meaningful-is the main theme of the third Critique. Beauty is, for Kant, the fundamental way in which nature appears meaningful for us; thus, the aesthetic power of judgment has priority over the teleological power of judgment discussed in the book's second part. See Critique of the Power of Judgment, 79 [AA 5:193].

28 Kant, Critique of the Power of Judgment, 178-179 [AA 5:299-300].

29 Abrams, "Art-as-Such," 139. For a critique of the teleological narrative similar to the one presented in this introduction, see Andrew Ashfield and Peter de Bolla, "Introduction," in The Sublime: A Reader in British EighteenthCentury Aesthetic Theory (Cambridge: Cambridge University Press, 1996), esp. 2-3. Ashfield and de Bolla stress that "in the British tradition there is a consistent refusal to relinquish the interconnections between aesthetic judgments and ethical conduct."

30 Two exceptions are Paul Guyer, The History of Modern Aesthetics, Vol. 1 (Cambridge: Cambridge University Press, 2014), 410-418, and Kai Hammermeister, The German Aesthetic Tradition (Cambridge: Cambridge University Press, 2002), 29 and 75.

31 Karl Philipp Moritz, "An Attempt to Unify All the Fine Arts and Sciences under the Concept of 'That Which Is Complete in Itself,"” trans. Elliott Schreiber, Publications of the Modern Language Association 127 (2012): 97 and 99.

32 Dieter Borchmeyer, Weimarer Klassik: Portrait einer Epoche, 2nd ed. (Weinheim: Beltz Athenäum, 1998), 141.

33 See, e.g., Christa Bürger, Der Ursprung der bürgerlichen Institution Kunst: Litteratursoziologische Untersuchungen zum klassischen Goethe (Frankfurt am Main: Suhrkamp, 1977), 119-130; Alessandro Costazza, Schönheit und Nützlichkeit: Karl Philipp Moritz und die Ästhetik des 18. Jahrhunderts (Bern: Peter Lang, 1996).

34 Mattias Pirholt, "Disinterested Love: Ethics and Aesthetics in Karl Philipp Moritz's 'Versuch einer Vereinigung aller schönen Künste und Wissenschaften unter dem Begriff des in sich selbst Vollendeten," Goethe Yearbook 27 (2020): 63-81.

35 Paul Guyer, Kant and the Experience of Freedom: Essays on Aesthetics and Morality (Cambridge: Cambridge University Press, 1993), 90-92; Martha 
Woodmansee, Author, Art and the Market: Rereading the History of Aesthetics (New York: Columbia University Press, 1994), 12; Jonathan Hess, Reconstituting the Body Politic: Enlightenment, Public Culture and the Invention of Aesthetic Autonomy (Detroit: Wayne State University Press, 1999), 157.

36 Wilhelm Voßkamp, "Klassik als Epoche: Zur Typologie und Funktion der Weimarer Klassik," in Epochenschwelle und Epochenbewußtsein, ed. Reinhart Herzog and Reinhart Koselleck (Munich: Fink, 1987), 496. See also Gerhard Sauder, "Ästhetische Autonomie als Norm der Weimarer Klassik," in Normen und Werte, ed. Friedrich Hiller (Heidelberg: Winter, 1982), 130-150.

37 Simon Richter, "Introduction," in The Literature of Weimar Classicism, ed. Simon Richter (Rochester: Camden House, 2005), 12.

38 Klaus L. Berghahn, "Mit dem Rücken zum Publikum: Autonomie der Kunst und literarische Öffentlichkeit in der Weimarer Klassik," in Revolution und Autonomie: Deutsche Autonomieästhetik im Zeitalter der Französischen Revolution, ed. Wolfgang Wittkowski (Tübingen: Niemeyer, 1990), 229; Dieter Borchmeyer, "Ästhetische und politische Autonomie: Schillers "Ästhetische Briefe' im Gegenlicht der Französischen Revolution,” in Revolution und Autonomie: Deutsche Autonomieästhetik im Zeitalter der Französischen Revolution, ed. Wolfgang Wittkowski (Tübingen: Niemeyer, 1990), 277-290.

39 Frederick Beiser, Schiller as Philosopher: A Re-Examination (Oxford: Oxford University Press, 2008), 212. See also Peter Bürger, Theorie der Avantgarde (Frankfurt am Main: Suhrkamp, 1974), 60-63; Guyer, Kant and the Experience of Freedom, 116-130; Hess, Reconstituting the Body Politic, 78-81; Sauder, "Ästhetische Autonomie als Norm der Weimarer Klassik," 137-142.

40 Rolf-Peter Janz argues that aesthetic and political autonomy are essentially unreconcilable since "the freedom of beautiful morality is merely a substitute for political freedom.” Rolf-Peter Janz, Autonomie und soziale Funktion: Studien zur Ästhetik von Schiller und Novalis (Stuttgart: Metzler, 1973), 66.

41 Herder's last two books, Metakritik (1799) and Kalligone (1800), are fullfledged attacks on Kant's critical philosophy. Particularly the latter of the two, a reading of Critique of the Power of Judgment, has been habitually ignored by Herder scholars.

42 For an illuminating description of the legacy of the third Critique focusing on its dual effect-claimed as either establishing the successful and desired division of separate value spheres (and thus as inaugurating modern aesthetic autonomy and indeed modernity as such) or as "the radical undoing of the categorial divisions between knowledge, morality and aesthetics" (thus leading to "a critique of enlightened modernity"), see J. M. Bernstein, The Fate of Art: Aesthetic Alienation from Kant to Derrida and Adorno (Cambridge: Polity, 1997 [1992]), 1-16 (quotes from page 7).

43 Kant, Critique of the Power of Judgment, 186 (\$46) [AA 5:307] (on genius) and 185-186 (\$45) [AA 5:306-307] (on the purposiveness of works of art).

44 F. W. J. Schelling, System of Transcendental Idealism, trans. Peter Heath (Charlottesville: University Press of Virginia, 1978), 225; System des transzendentalen Idealismus, in Sämmtliche Werke, ed. K. F. A. Schelling, Vol. I/3 (Stuttgart: Cotta, 1858), 619.

45 F. W. J. Schelling, "Ueber das Verhältnis der bildenden Künste zu der Natur," in Sämmtliche Werke, ed. K. F. A. Schelling, Vol. I/7 (Stuttgart: Cotta 1860), 293. 
46 Andrew Bowie also frames the development of aesthetics as a response to the increasing exploitation and domination of nature. See Bowie, Aesthetics and Subjectivity: From Kant to Nietzsche, 2nd ed. (Manchester: Manchester University Press, 2003), esp. 3-8.

47 Immanuel Kant, Critique of Practical Reason, in Kant, Practical Philosophy, trans. Mary Gregor (Cambridge and New York: Cambridge University Press, 1996), 268 [AA 5:160].

48 For further discussion, see Dalia Nassar, “Analogical Reflection as a Source for the Science of Life: Kant and the Possibility of the Biological Sciences," Studies in History and Philosophy of Science 58 (2016): 57-66. doi:10.1016/j.shpsa.2016.03.008.

\section{Bibliography}

Abrams, M. H. “Art-as-Such: The Sociology of Modern Aesthetics.” In Doing Things with Texts: Essays in Criticism and Critical Theory, 135-158. New York: W. W. Norton, 1989.

Addison, Joseph. "The Pleasures of the Imagination.” In The Spectator, edited by Donald F. Bond, Vol. 3 [no. 411-421], 535-582. Oxford: Oxford University Press, 1965.

Arregui, Jorge V., and Pablo Arnau. "Shaftesbury: Father or Critic of Modern Aesthetics?" British Journal of Aesthetics 34, no. 4 (1994): 350-362.

Ashfield, Andrew, and Peter de Bolla. "Introduction." In The Sublime: A Reader in British Eighteenth-Century Aesthetic Theory, edited by Andrew Ashfield and Peter de Bolla, 1-16. Cambridge: Cambridge University Press, 1996.

Axelsson, Karl. "Joseph Addison and General Education: Moral Didactics in Early Eighteenth-Century Britain.” Estetika: The Central European Journal of Aesthetics 46, no. 2 (2009): 144-166.

Axelsson, Karl. Political Aesthetics: Addison and Shaftesbury on Taste, Morals and Society. London: Bloomsbury, 2019.

Baumgarten, Alexander Gottlieb. Ästhetik. Edited and translated by Dagmar Mirbach. Vol. 1. Hamburg: Meiner, 2007.

Beiser, Frederick. Schiller as Philosopher: A Re-Examination. Oxford: Oxford University Press, 2008.

Berghahn, Klaus L. "Mit dem Rücken zum Publikum: Autonomie der Kunst und literarische Öffentlichkeit in der Weimarer Klassik." In Revolution und Autonomie: Deutsche Autonomieästhetik im Zeitalter der Französischen Revolution, edited by Wolfgang Wittkowski, 207-229. Tübingen: Niemeyer, 1990.

Bernstein, J. M. The Fate of Art: Aesthetic Alienation from Kant to Derrida and Adorno. Cambridge: Polity, 1997 [1992].

Borchmeyer, Dieter. "Ästhetische und politische Autonomie: Schillers “Ästhetische Briefe' im Gegenlicht der Französischen Revolution.” In Revolution und Autonomie: Deutsche Autonomieästhetik im Zeitalter der Französischen Revolution, edited by Wolfgang Wittkowski, 277-290. Tübingen: Niemeyer, 1990.

Borchmeyer, Dieter. Weimarer Klassik: Portrait einer Epoche. 2nd ed. Weinheim: Beltz Athenäum, 1998. 
Bowie, Andrew. Aesthetics and Subjectivity: From Kant to Nietzsche. 2nd ed. Manchester: Manchester University Press, 2003.

Bürger, Christa. Der Ursprung der bürgerlichen Institution Kunst: Litteratursoziologische Untersuchungen zum klassischen Goethe. Frankfurt am Main: Suhrkamp, 1977.

Bürger, Peter. Theorie der Avantgarde. Frankfurt am Main: Suhrkamp, 1974. Costazza, Alessandro. Schönheit und Nützlichkeit: Karl Philipp Moritz und die Ästhetik des 18. Jahrhunderts. Bern: Peter Lang, 1996.

Guyer, Paul. The History of Modern Aesthetics. Vol. 1. Cambridge: Cambridge University Press, 2014.

Guyer, Paul. Kant and the Experience of Freedom: Essays on Aesthetics and Morality. Cambridge: Cambridge University Press, 1993.

Hammermeister, Kai. The German Aesthetic Tradition. Cambridge: Cambridge University Press, 2002.

Haskins, Casey. "Autonomy: Overview." In The Encyclopedia of Aesthetics, edited by Michael Kelly, 2nd ed., Vol. 1, 247-252. New York: Oxford University Press, 2014.

Haskins, Casey. "The Myth of the Autonomy Fault Line in Aesthetics." In Aesthetic and Artistic Autonomy, edited by Owen Hulatt, 113-145. London: Bloomsbury, 2013.

Hess, Jonathan. Reconstituting the Body Politic: Enlightenment, Public Culture and the Invention of Aesthetic Autonomy. Detroit: Wayne State University Press, 1999.

Janz, Rolf-Peter. Autonomie und soziale Funktion: Studien zur Ästhetik von Schiller und Novalis. Stuttgart: Metzler, 1973.

Kant, Immanuel. Critique of Practical Reason. In Practical Philosophy, translated by Mary Gregor. Cambridge and New York: Cambridge University Press, 1996.

Kant, Immanuel. Critique of the Power of Judgment. Edited by Paul Guyer, translated by Paul Guyer and Eric Matthews. Cambridge: Cambridge University Press, 2000.

Kivy, Peter. "Recent Scholarship and the British Tradition: A Logic of TasteThe First Fifty Years." In Aesthetics: A Critical Anthology, edited by George Dickie, Richard Sclafani, and Ronald Roblin, 2nd ed., 254-268. New York: St Martin's Press, 1989.

Kivy, Peter. "What Really Happened in the Eighteenth Century: The 'Modern System' Re-examined (Again).” British Journal of Aesthetics 52, no. 1 (2012): 61-74.

Kristeller, Paul Oskar. "The Modern System of the Arts: A Study in the History of Aesthetics (I)." Journal of the History of Ideas 12, no. 4 (1951): 496-527.

Kristeller, Paul Oskar. "The Modern System of the Arts: A Study in the History of Aesthetics (II)." Journal of the History of Ideas 13, no. 1 (1952): 17-46.

Monk, Samuel H. The Sublime: A Study of Critical Theories in EighteenthCentury England. New York: Modern Language Association of America, 1935.

Moritz, Karl Philipp. “An Attempt to Unify All the Fine Arts and Sciences under the Concept of 'That Which Is Complete in Itself."' Translated by Elliott Schreiber. Publications of the Modern Language Association 127 (2012): 97-100. 
Nassar, Dalia. "Analogical Reflection as a Source for the Science of Life: Kant and the Possibility of the Biological Sciences." Studies in History and Philosophy of Science 58 (2016): 57-66. doi:10.1016/j.shpsa.2016.03.008.

Pirholt, Mattias. "Disinterested Love: Ethics and Aesthetics in Karl Philipp Moritz's 'Versuch einer Vereinigung aller schönen Künste und Wissenschaften unter dem Begriff des in sich selbst Vollendeten.'” Goethe Yearbook 27 (2020): 63-81.

Porter, James I. "Is Art Modern? Kristeller's 'Modern System of the Arts' Reconsidered." British Journal of Aesthetics 49, no. 1 (2009): 1-24.

Richter, Simon. "Introduction." In The Literature of Weimar Classicism, edited by Simon Richter, 1-44. Rochester: Camden House, 2005.

Rind, Miles. "The Concept of Disinterestedness in Eighteenth-Century British Aesthetics." Journal of the History of Philosophy 40, no. 1 (2002): 67-87.

Sauder, Gerhard. "Ästhetische Autonomie als Norm der Weimarer Klassik." In Normen und Werte, edited by Friedrich Hiller, 130-150. Heidelberg: Winter, 1982.

Schelling, F. W. J. System of Transcendental Idealism. Translated by Peter Heath. Charlottesville: University Press of Virginia, 1978.

Schelling, F. W. J. System des transzendentalen Idealismus. In Sämmtliche Werke, edited by K. F. A. Schelling, Vol. I/3. Stuttgart: Cotta, 1858.

Schelling, F. W. J. "Ueber das Verhältnis der bildenden Künste zu der Natur.” In Sämmtliche Werke, edited by K. F. A. Schelling, Vol. I/7, 289-329. Stuttgart: Cotta, 1860.

Shiner, Larry. "Continuity and Discontinuity in the Concept of Art." British Journal of Aesthetics 49, no. 2 (2009): 159-169.

Stolnitz, Jerome. "On the Significance of Lord Shaftesbury in Modern Aesthetic Theory.” Philosophical Quarterly 11, no. 43 (1961): 97-113.

Stolnitz, Jerome. "A Third Note on Eighteenth-Century 'Disinterestedness.'” Journal of Aesthetics and Art Criticism 22, no. 1 (1963): 69-70.

Voßkamp, Wilhelm. "Klassik als Epoche: Zur Typologie und Funktion der Weimarer Klassik." In Epochenschwelle und Epochenbewußtsein, edited by Reinhart Herzog and Reinhart Koselleck, 493-514. Munich: Fink, 1987.

Wolterstorff, Nicholas. Art Rethought: The Social Practices of Art. Oxford: Oxford University Press, 2015.

Woodmansee, Martha. Author, Art and the Market: Rereading the History of Aesthetics. New York: Columbia University Press, 1994. 
